\title{
Metabolism is required for chemotaxis to sugars in Rhodobacter sphaeroides
}

\author{
Yehudit Jeziore-Sassoon, † Paul A. Hamblin, \\ Carolyn A. Bootle-Wilbraham, Philip S. Poole $\neq$ and Judith P. Armitage
}

Author for correspondence: Judith P. Armitage. Tel: +44 1865 275299. Fax: +44 1865275297. e-mail: armitage@bioch.ox.ac.uk

Microbiology Unit, Department of Biochemistry, University of Oxford, South Parks Road, Oxford OX1 3QU, UK

\begin{abstract}
Chemotaxis towards carbohydrates is mediated, in enteric bacteria, either by the transport-independent, methylation-dependent chemotaxis pathway or by transport and phosphorylation via the phosphoenolpyruvate (PEP)-dependent phosphotransferase system (PTS). This study shows that Rhodobacter sphaeroides is chemotactic to a range of carbohydrates but the response involves neither the classical methyl-accepting chemotaxis protein (MCP) pathway nor the PTS transport pathway. The chemoattractant fructose was transported by a fructose-specific PTS system, but transport through this system did not appear to cause a chemotactic signal. Chemotaxis to sugars was inducible and occurred with the induction of carbohydrate transport systems and with substrate incorporation. A mutation of the glucose-6-phosphate dehydrogenase gene (zwf) inhibited chemotaxis towards substrates metabolized by this pathway although transport was unaffected. Chemotaxis to other, unrelated, chemoattractants (e.g. succinate) was unaffected. These data, in conjunction with the fact that mannitol and fructose (which utilize different transport pathways) compete in chemotaxis assays, suggest that in $R$. sphaeroides the chemotactic signal is likely to be generated by metabolic intermediates or the activities of the electron-transport chain and not by a cellsurface receptor or the rate or mode of substrate transport.
\end{abstract}

Keywords: Rhodobacter sphaeroides, chemotaxis, bacteria, carbohydrate transport, phosphotransferase system

\section{INTRODUCTION}

The chemotactic systems in enteric bacteria and in the purple photosynthetic bacterium Rhodobacter sphaeroides are fundamentally different (Armitage et al., 1990a; Armitage, 1992; Armitage \& Schmitt, 1997). In enteric bacteria, chemical gradients are usually detected via methyl-accepting chemotaxis proteins (MCPs) which span the cytoplasmic membrane (Hazelbauer et al., 1990). In response to a decrease in chemoeffector concentration, the cytoplasmic domain of the MCPs activates the histidine protein kinase, CheA, resulting in the autophosphorylation of CheA on a conserved histidine

\footnotetext{
†Present address: Institut für Allgemeine Mikrobiologie, Universität Bern, Baltzerstrasse 4, 3012-Bern, Switzerland.

¥Present address: School of AMS, University of Reading, Whiteknights, Reading RG6 6A, UK.

Abbreviations: $M C P$, methyl-accepting chemotaxis protein; PEP, phosphoenolpyruvate; PTS, phosphotransferase system.
}

residue (H48) (Hess et al., 1988). An accessory protein, $\mathrm{CheW}$, is absolutely required as a link between CheA and the MCPs (Conley et al., 1989). CheA-phosphate phosphorylates CheY (a response regulator), which in turn interacts with the switch proteins of the flagellar motor, causing the bacterium to tumble. The signal is terminated by $\mathrm{CheZ}$, which enhances the intrinsic autophosphatase activity of CheY (Blat $\&$ Eisenbach, 1994). Adaptation to the continued presence of a chemoattractant is mediated by CheB (a methylesterase) and CheR (a methyltransferase), which together control the level of methylation of the MCPs at conserved glutamate residues (Stock et al., 1985; Yonekawa et al., 1983).

A chemotaxis operon has been identified in $R$. sphaeroides containing homologues of the enteric che A, che W, cheR and two cheY genes, but lacking cheB and che Z homologues (Ward et al., 1995a). In contrast to the enterics, mutation of these chemotaxis genes in $R$. sphaeroides has little effect on chemotaxis to most chemoattractants (Hamblin et al., 1997). Although two 
$m c p$ homologues have been identified in this $R$. sphaeroides chemotaxis operon, unlike the situation in Escherichia coli, McpA of $R$. sphaeroides is not the receptor for a specific chemoattractant but instead is involved in responses to a range of chemoattractants under aerobic conditions (Ward et al., 1995b). The principal chemoattractants for this organism include weak organic acids, many of which are strong repellents for enteric bacteria. It has been shown that all known attractants for $R$. sphaeroides are either metabolites or simple ions that affect metabolism and that transport of the attractant is necessary to elicit a tactic response (Jacobs et al., 1995; Ingham \& Armitage, 1987). In addition, at least limited metabolism is required for responses towards ammonia and L-alanine (Poole \& Armitage, 1989; Poole et al., 1993).

Some chemotactic responses in enteric bacteria are not mediated by MCPs (Niwano \& Taylor, 1982). A major MCP-independent system is the phosphoenolpyruvate (PEP)-dependent sugar phosphotransferase system (PTS) (Lengeler \& Vogler, 1989). The PTS is a group translocation system consisting of membrane-bound protein kinases (enzymes II, EII) specific for the transport and concomitant phosphorylation of a wide range of carbohydrates (Saier, 1989, 1993; Saier et al., 1990). EIIs are phosphorylated as a result of cytoplasmic phosphoryl transfer reactions catalysed by the soluble protein kinases enzyme I (EI) and $\mathrm{HPr}$ (histidinecontaining protein), with PEP acting as the phosphoryl donor. EI and $\mathrm{HPr}$ are general PTS components, necessary for the uptake of all PTS carbohydrates except $D$-fructose. Fructose regulates the expression of its own $\mathrm{HPr}$-like protein called pseudo-HPr or FPr (Geerse et al., 1989), which has significant primary sequence homology to $\mathrm{HPr}$ and can substitute for $\mathrm{HPr}$ if constitutively expressed (Holzapfel et al., 1990). Mutants of enteric bacteria in which the HPr protein was replaced by a constitutively expressed FPr were normal for transport and phosphorylation but they showed no chemotaxis to PTS substrates. The data suggest that the rate of phosphorylation during FPr-dependent transport was sufficient to allow transport but not chemotactic signalling. Chemotaxis towards PTS-dependent carbohydrates requires CheA, CheY and CheW but not the MCPs (Rowsell et al., 1995). The chemotactic signal is dependent on the rate of phosphorylation through the HPr-dependent PTS transport pathway; unphosphorylated EI enzyme can interact and inhibit the autophosphorylation of CheA (Lux et al., 1995; Grübl et al., 1990; Lengeler \& Vogler, 1989).

Saier and co-workers have shown that fructose is the only carbohydrate transported through a PTS in $R$. sphaeroides. This system is related to the FPr system identified in enteric bacteria, but with the EIII, FPr and EI domains located on a single protein (Wu et al., 1990, 1991). As chemotaxis to carbohydrates in enteric bacteria appears to use either MCP-based or HPr-dependent PTS-based chemotactic signalling we investigated the chemotactic responses of $R$. sphaeroides to carbohydrates. By studying both transport mechanisms and several early steps in carbohydrate metabolism, and relating our results to investigations of chemotaxis, we have attempted to make general comparisons between the chemotactic systems in $R$. sphaeroides and the MCPindependent systems in enteric bacteria. The role of metabolism in $R$. sphaeroides chemotaxis was also investigated using a mutation in glucose-6-phosphate dehydrogenase, a key enzyme in the Entner-Doudoroff and pentose phosphate pathways.

\section{METHODS}

Strains and growth conditions. $R$. sphaeroides WS8 was a gift from W. R. Sistrom (University of Oregon). R. sphaeroides WS8N was a spontaneous nalidixic-acid-resistant derivative of WS8 (Sockett et al., 1990). Escherichia coli DH5 $\alpha$ was

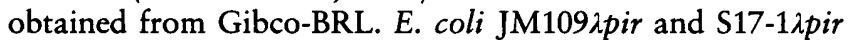
were provided by R. Penfold (University of Queensland, Australia). Strains and plasmids used in this study are shown in Table 1.

$R$. sphaeroides was grown in liquid cultures at $30^{\circ} \mathrm{C}$ under either aerobic conditions in the dark or in an illuminated anaerobic cabinet. The medium was either a modified Hutners (succinate) medium supplemented with $0 \cdot 1 \%$ Casamino acids or a minimal M22 medium (Armitage et al., 1985), supplemented with either succinate or a carbohydrate such as fructose, glucose or mannitol at $2 \mathrm{~g} \mathrm{l}^{-1}$. Cells were harvested in late-exponential phase at a density of approximately $10^{9}$ cells $\mathrm{ml}^{-1}$ and suspended in $10 \mathrm{mM}$ HEPES/NaOH ( $\mathrm{pH} 7 \cdot 2$ ). For anaerobic cells, the HEPES/ $\mathrm{NaOH}$ buffer was sparged with nitrogen for at least $20 \mathrm{~min}$. E. coli strains were grown in Luria-Bertani (LB) medium at $37^{\circ} \mathrm{C}$ with appropriate antibiotics. For $E$. coli, antibiotics were used at the following concentrations; ampicillin, $100 \mu \mathrm{g} \mathrm{ml}^{-1}$; kanamycin, 25 $\mu \mathrm{g} \mathrm{ml}^{-1}$; chloramphenicol, $50 \mu \mathrm{g} \mathrm{ml}^{-1}$. For $R$. sphaeroides, antibiotics were used as above, and also nalidixic acid at $20 \mu \mathrm{g} \mathrm{ml}^{-1}$.

Chemotaxis and motility assays. Qualitative measurements of chemotaxis were performed in soft agar plates with plugs of attractant as described by Poole et al. (1993). Motile bacteria were washed in sparged $10 \mathrm{mM}$ HEPES/ $\mathrm{NaOH}(\mathrm{pH} 7 \cdot 2$ ), to remove all traces of growth medium, and resuspended at a density of approximately $4 \times 10^{9}$ cells $\mathrm{ml}^{-1}$ in $0.25 \% \mathrm{w} / \mathrm{v}$ Difco Bacto-agar made up in $10 \mathrm{mM}$ HEPES/NaOH and containing chloramphenicol $\left(50 \mu \mathrm{g} \mathrm{ml}^{-1}\right)$ to inhibit protein synthesis and growth around the attractant plugs. At this stage backgrounds of competitor chemicals at $100 \mathrm{mM}$ were added to the agar if required. Hard agar plugs $(2.5 \%$ agar $)$ containing $20 \mathrm{mM}$ attractant were cut with a $5 \mathrm{~mm}$ cork borer and inserted into the soft agar/cell suspension. The bacteria were incubated in a Petri dish under aerobic dark or anaerobic light conditions. After approximately $2-4 \mathrm{~h}$ incubation, a chemotactic response was observed as a ring of accumulation around the hard agar plugs.

$R$. sphaeroides swarm plates were prepared from M22 media containing $0.22 \%$ agar and $100 \mu \mathrm{M}$ carbon source. Stationaryphase culture $(5 \mu \mathrm{l})$ was pipetted onto the surface of the agar and the plates incubated aerobically in the dark or anaerobically in the light for $24-48 \mathrm{~h}$, after which time the distance travelled by the growing cells up a concentration gradient created by metabolism was measured. Plug plates and swarm plates were scored as a qualitative measure of responses 
Table 1. Strains and plasmids used

\begin{tabular}{|c|c|c|}
\hline $\begin{array}{l}\text { Strain or } \\
\text { plasmid }\end{array}$ & Characteristic & Source/reference \\
\hline \multicolumn{3}{|l|}{ E. coli } \\
\hline DH5 $\alpha$ & General cloning strain & Gibco-BRL \\
\hline JM109 גpir & $\begin{array}{l}\text { Cloning strain for pJP5603, derivative of } \\
\text { JM109 with } \lambda \text { pir on chromosome }\end{array}$ & $\begin{array}{l}\text { Gift from R. Penfold } \\
\text { (Miller \& Mekalanos, 1988) }\end{array}$ \\
\hline S17-1 $\lambda$ pir & $\begin{array}{l}\text { Conjugative strain for pJP5603, } \lambda \text { pir and } \\
\text { mobilizing factors on chromosome }\end{array}$ & $\begin{array}{l}\text { Gift from R. Penfold } \\
\text { (Penfold \& Pemberton, 1992) }\end{array}$ \\
\hline \multicolumn{3}{|c|}{ R. sphaeroides } \\
\hline WS8 & Wild-type chemotaxis strain & Gift from W. Sistrom \\
\hline WS8N & $\begin{array}{l}\text { Spontaneous nalidixic-acid-resistant } \\
\text { derivative of WS8 }\end{array}$ & This laboratory \\
\hline JPA117 & $\begin{array}{l}\text { Derivative of WS8N with deletion of } \\
\text { chemotaxis operon, } \mathrm{Nal}^{\mathrm{r}}\end{array}$ & This laboratory \\
\hline JPA131 & Tn5 mutant of JPA117, $\mathrm{Km}^{\mathrm{r}} \mathrm{Nal}^{\mathrm{r}}$ & This study \\
\hline JPA142 & $z w f$-deficient mutant of WS8N, $\mathrm{Km}^{\mathrm{r}} \mathrm{Nal}^{\mathrm{r}}$ & This study \\
\hline JPA141 & $z w f$-deficient mutant of JPA117, $\mathrm{Km}^{\mathrm{r}} \mathrm{Nal}^{\mathrm{r}}$ & This study \\
\hline \multicolumn{3}{|l|}{ Plasmids } \\
\hline pUC18 & General cloning vector; $A p^{r}$ & $\begin{array}{l}\text { Messing (1983), Yanisch- } \\
\text { Perron et al. (1985) }\end{array}$ \\
\hline pJP5603 & Mobilizable suicide vector, $\mathrm{Km}^{\mathrm{r}}$ & $\begin{array}{l}\text { Gift from R. Penfold } \\
\text { (Penfold \& Pemberton, 1992) }\end{array}$ \\
\hline pAUL57 & $\begin{array}{l}\text { pUC18 containing } 9.5 \mathrm{kbp} \text { kanamycin- } \\
\text { resistant EcoRI fragment from JPA131, Ap } \\
\mathrm{Km}^{\mathrm{r}}\end{array}$ & This study \\
\hline pAUL65 & $\begin{array}{l}\text { pUC18 containing } 0.7 \mathrm{kbp} \mathrm{Hpal} / E c o \mathrm{RI} \\
\text { fragment of pAUL57, } \mathrm{Ap}^{\mathrm{r}}\end{array}$ & This study \\
\hline pBM1 & $\begin{array}{l}\text { pJP5603 containing } 0.4 \mathrm{kbp} E c o \mathrm{RI} / B g l \mathrm{II} \\
\text { fragment of pAUL65, } \mathrm{Km}^{\mathrm{r}}\end{array}$ & This study \\
\hline
\end{tabular}

according to both the diameter of the rings and the intensity of the response.

The behaviour of individual tethered cells was analysed using computerized motion analysis. Cells from late-exponentialphase culture $(1 \mathrm{ml})$ were harvested and resuspended in $100 \mu \mathrm{l}$ of $10 \mathrm{mM}$ HEPES/NaOH buffer ( $\mathrm{pH} 7 \cdot 2$ ) containing chloramphenicol $\left(50 \mu \mathrm{g} \mathrm{ml}^{-1}\right)$. The cells were tethered in a humidity chamber by incubating $9 \mu$ cell suspension with $3 \mu \mathrm{l}$ antiflagellar antibody. After $30 \mathrm{~min}$ incubation the coverslip was loaded onto a flow chamber (Berg \& Block, 1984) and equilibrated for $30 \mathrm{~min}$ with $\mathrm{HEPES} / \mathrm{NaOH}(\mathrm{pH} 7 \cdot 2)$. The cells were observed by phase-contrast microscopy at $\times 1000$ magnification. HEPES/NaOH buffers $(\mathrm{pH} 7 \cdot 2$ ) containing known chemoeffectors were passed through the chamber and the behaviour of the tethered cells was analysed using a computerized motion analysis system (Seescan Electronics) described previously (Poole et al., 1988). The rotational behaviour of each cell was determined by observing the position of the cell body every $0.06 \mathrm{~s}$ for $900 \mathrm{~s}$. The data for 10-14 cells were averaged, smoothed and plotted.

The behaviour of free-swimming cells was measured by drawing a culture into an $0.05 \mathrm{~mm}$ deep optically flat microslide (Camlabs) which was sealed with vaseline. Cells were viewed at $\times 1000$ magnification and about 2000 cells tracked over a $165 \mathrm{~s}$ period using a real-time Hobson Bactracker system (Hobson Tracking Systems). The mean velocity $\left(\mu \mathrm{m} \mathrm{s}^{-1}\right)$ and stopping frequency (SPF, stops $\left.\mathrm{s}^{-1}\right)$ of the cells was measured for three periods of $165 \mathrm{~s}$ and the data averaged.

Transport assays. Cells were harvested at $10000 \mathrm{~g}$ for $10 \mathrm{~min}$, washed and resuspended in nitrogen-sparged HEPES at a concentration of $10^{9} \mathrm{cells} \mathrm{ml}^{-1}$. Samples were incubated under aerobic dark or anaerobic light conditions to deplete the cells of endogenous energy stores. Uptake was initiated by the addition of $0.5 \mu \mathrm{Ci}(18.5 \mathrm{kBq}) \mathrm{U}^{-14} \mathrm{C}$-labelled solute to a final concentration of $4 \mu \mathrm{M}$. If potential competitors were used, $100 \mu \mathrm{M}$ competitor substrate was added to the starved bacterial suspension just before the addition of the radiolabelled test solute. Samples $(100 \mu \mathrm{l})$ were filtered with suction through Whatman GF/F glass fibre filters $(0.7 \mu \mathrm{m}$ retention) every 15-30 s, using a Millipore sampling manifold. Samples were washed immediately with $5 \mathrm{ml}$ HEPES and placed into $3 \mathrm{ml}$ Optiphase HiSafe scintillation fluid and radioactivity measured using a Beckman LS 5000TD scintillation counter.

For measurement of trichloroacetic-acid-precipitable material, representing the incorporation of the test substrate into cell material, a final volume of $1 \mathrm{ml}$ cell suspension in HEPES was used. Assays were initiated by the addition of $4 \mu \mathrm{M}(0.5 \mu \mathrm{Ci}){ }^{14} \mathrm{C}$-labelled test substrate. Samples $(100 \mu \mathrm{l})$ were removed at intervals over a $15 \mathrm{~min}$ period and injected into $3 \mathrm{ml}$ ice-cold trichloroacetic acid $(10 \%, w / v)$. After $30 \mathrm{~min}$ incubation on ice, the samples were filtered through Whatman GF/F filters and radioactivity was measured as described above. 
Preparation of cell fractions. Crude extracts, cytoplasmic fractions and membrane fractions were prepared as described by Daniels et al. (1988) with a few modifications. Cells were harvested, washed and resuspended in $25 \mathrm{mM}$ Tris $/ \mathrm{HCl}$ (pH 8.0), containing $0.5 \mathrm{mM}$ DTT, $10 \mathrm{mM}$ EDTA, $100 \mu \mathrm{g}$ lysozyme $\mathrm{ml}^{-1}, 29 \mu \mathrm{g}$ DNase $\mathrm{ml}^{-1}, 10 \mu \mathrm{g}$ RNase $\mathrm{ml}^{-1}$ and $15 \mathrm{mM} \mathrm{MgCl}_{2}$ and ruptured by two passages through a French pressure cell (SLM AMINCO) at $69000 \mathrm{KPa}$ maintained at $4{ }^{\circ} \mathrm{C}$. Cellular debris was removed by centrifugation at $12000 \mathrm{~g}$ for $20 \mathrm{~min}$. The cell-free supernatant was then centrifuged at $120000 \mathrm{~g}$ for $2 \mathrm{~h}$, to separate the cytoplasmic and membrane fractions. All procedures were performed at $4^{\circ} \mathrm{C}$.

Enzyme assays. The phosphorylation activity of the PEPdependent PTS was measured using an adaptation of the method of Saier et al. (1971). The phosphorylation reaction was carried out at $30^{\circ} \mathrm{C}$ in a final volume of $200 \mu \mathrm{l}$ and contained $25 \mathrm{mM}$ Tris/ $\mathrm{HCl}$ ( $\mathrm{pH} 7 \cdot 8$ ), $1 \mathrm{M}$ potassium fluoride, $100 \mathrm{mM}$ DTT, $0.5 \mathrm{M}$ PEP, $1 \mathrm{M} \mathrm{MgCl}_{2}, 2 \mathrm{mg}$ protein membrane extract $\mathrm{ml}^{-1}$ and a fourfold excess by volume of cytoplasmic extract. The reaction was initiated by the addition of $100 \mathrm{mM} \mathrm{U-}{ }^{14} \mathrm{C}$-labelled $\mathrm{D}$-carbohydrate as the phosphate acceptor, at an activity of $7 \mu \mathrm{Ci} \mathrm{m}^{-1} ; 20 \mu \mathrm{l}$ portions were taken at time intervals and filtered through a stack of three DEAE-cellulose filters (Whatman DE $812.3 \mathrm{~cm}$ discs). Discs were allowed to dry for $30 \mathrm{~min}$ at room temperature and were then washed with distilled water. The filter stacks, which retain sugar phosphates, were then placed into $3 \mathrm{ml}$ Optiphase HiSafe for scintillation counting.

Mannitol dehydrogenase (EC 1.1.1.67) activity was measured in a reaction mixture containing $0.2 \mathrm{mM} \mathrm{NAD}{ }^{+}$, $10 \mathrm{mM}$ mannitol, $1 \mathrm{mM}$ DTT and $500 \mu \mathrm{g}$ cytoplasmic extract $\mathrm{ml}^{-1}$ in $50 \mathrm{mM}$ Tris $/ \mathrm{HCl}$ buffer at $\mathrm{pH} 8.9$ and $30^{\circ} \mathrm{C}$. The conversion of mannitol to fructose was observed spectrophotometrically as the reduction of $\mathrm{NAD}^{+}$at $340 \mathrm{~nm}$.

Fructokinase (EC 2.7.1.4) reaction mixture contained $0.2 \mathrm{mM}$ ATP, $10 \mathrm{mM} \mathrm{MgCl}, 10 \mathrm{mM}$ fructose, $0.2 \mathrm{mM}$ $\mathrm{NADP}^{+}, 3 \mathrm{U}$ phosphoglucose isomerase (EC 5.3.1.9), $3 \mathrm{U}$ glucose-6-phosphate dehydrogenase (EC 1.1.1.49) and $500 \mu \mathrm{g}$ cytoplasmic fraction $\mathrm{ml}^{-1}$ at $\mathrm{pH} 8.0$ in $50 \mathrm{mM}$ Tris $/ \mathrm{HCl}$ buffer. The isomerase converted fructose 6-phosphate to glucose 6-phosphate, which was then acted upon by the dehydrogenase. The concomitant reduction of $\mathrm{NADP}^{+}$was followed optically at $340 \mathrm{~nm}$.

Fructose-6-phosphate kinase (EC 2.7.1.11) was measured using a method from Fraenkel (1968). The reaction mixture contained $1 \mathrm{mM}$ fructose 6-phosphate, $1 \mathrm{mM}$ ATP, $5 \mathrm{mM}$ $\mathrm{MgCl}_{2}, 5 \mathrm{mM}$ DTT, $20 \mathrm{mM}$ potassium phosphate buffer at pH 6.5, 0.15 mM NADH, 2 U fructose-1,6-bisphosphate aldolase (EC 4.1.2.13), 2 U glycerol-3-phosphate dehydrogenase (EC 1.1.1.8), $2 \mathrm{U}$ triose-phosphate isomerase (EC 5.3.1.1) and $500 \mu \mathrm{g}$ cytoplasmic fraction $\mathrm{ml}^{-1}$. The decrease in absorbance accompanying the oxidation of NADH was observed spectrophotometrically at $340 \mathrm{~nm}$.

Fructose-1-phosphate kinase (EC2.7.1.56) measurement was again adapted from a method of Fraenkel (1968). The reaction mixture contained $10 \mathrm{mM} \mathrm{MgCl}, 0.1 \mathrm{mM} \mathrm{NADH}, 1 \mathrm{mM}$ fructose 1-phosphate, $2 \mathrm{mM}$ ATP, $2 \mathrm{U}$ fructose-1,6-bisphosphate aldolase, 2 U glycerol-3-phosphate dehydrogenase, $2 \mathrm{U}$ triose-phosphate isomerase. The oxidation of NADH was observed spectrophotometrically at $340 \mathrm{~nm}$.

Glucose-6-phosphate dehydrogenase reaction mixture contained $0.2 \mathrm{mM}$ ATP, $10 \mathrm{mM} \mathrm{MgCl}_{2}, 0.2 \mathrm{mM}$ NADP, $10 \mathrm{mM}$ glucose 6-phosphate, $500 \mu \mathrm{g}$ soluble protein extract $\mathrm{ml}^{-1}$ in $50 \mathrm{mM}$ Tris/ $\mathrm{HCl}$ buffer. The formation of NADPH was concomitant with the formation of 6-phosphogluconate. The reaction was carried out at $30^{\circ} \mathrm{C}$ and $\mathrm{pH} 8.9$.

Genetic techniques. Chromosomal DNA was prepared and plasmid preparations were performed by the Birnboim \& Doly (1979) mini-prep technique or the Magic Miniprep system (Promega). Southern blotting was carried out using capillary transfer onto Hybond-N membranes and hybridized with probes generated using the random hexanucleotide priming method and digoxigenin-11-dUTP (Boehringer Mannheim). Hybridized fragments were visualized according to the manufacturer's immunodetection protocol. Standard cloning procedures were used throughout for the construction of plasmids. Constructs were transformed into E. coli $\mathrm{DH} 5 \alpha$, JM109 $\lambda$ pir or S17-1 $\lambda$ pir using the calcium chloride method of Cohen (Sambrook et al., 1989). E. coli JM109 $\lambda$ pir or S17-1 $\lambda$ pir were used to propagate plasmids pJP5603, pSUP2021 and their derivatives.

Sequencing reactions were performed on dsDNA by the dideoxy chain-termination method of Sanger using the Sequenase kit (Amersham) (Tabor \& Richardson, 1987) and $\left[{ }^{35} \mathrm{~S}\right] \mathrm{dATP} \alpha-\mathrm{S}\left(410 \mathrm{Ci} \mathrm{mmol}^{-1}, 15 \cdot 2 \mathrm{TBq} \mathrm{mmol}^{-1}\right.$; Amersham). Samples were run on $6 \%$ polyacrylamide gels prepared using National Diagnostics Sequagel reagents. Oligonucleotide primers were prepared using $\beta$-cyanoethylphosphoramidite chemistry on an Applied Biosystems model 381A automated DNA synthesizer, deprotected overnight and precipitated using sodium acetate/ethanol and diluted to a working concentration of $5 \mathrm{pmol} \mu \mathrm{l}^{-1}$. Primers used in this study $\left(5^{\prime} \rightarrow 3^{\prime}\right)$ are as follows; Tn5SEQ, TCCTGGAAAACGGGAAAGG; pUC18FOR, GTTTTCCCAGTCACGAC; pUC18REV, CAGGAAACAGCTATGAC.

Transposon mutagenesis of $R$. sphaeroides JPA117. JPA117 is a derivative of WS8N. An operon encoding homologues of the enteric chemotaxis proteins was deleted but the chemotactic phenotype of this mutant remained similar to wild-type (unpublished data). This strain, therefore, was used as the parent strain in an attempt to identify additional genes involved in sugar chemotaxis. pSUP2021, harbouring the transposon $\operatorname{Tn} 5:: \mathrm{Km}$ was mobilized into $R$. sphaeroides JPA117 from E. coli S17-1 $\lambda$ pir as described by Simon et al. (1983a, b). Transposon mutants were selected on agar plates containing M22 medium, $7 \mathrm{mM}$ succinate, $0 \cdot 1 \%$ Casamino acids, nalidixic acid $\left(20 \mu \mathrm{g} \mathrm{ml}^{-1}\right)$ and kanamycin $\left(25 \mu \mathrm{g} \mathrm{ml}^{-1}\right)$. A total of 1000 single colonies were picked and grown independently and the cultures were tested for loss of chemotaxis using the swarm plate assay described above. The swarm plates were made from M22 medium containing $0.22 \%$ bactoagar, $100 \mu \mathrm{M}$ mannitol and nalidixic acid $\left(20 \mu \mathrm{g} \mathrm{ml}^{-1}\right)$ inoculated with $5 \mu \mathrm{l}$ of stationary-phase culture and incubated aerobically. Transposon mutants were also plated directly into swarm agar, such that a large number of mutants could be rapidly screened. Reduced swarmers were selected and their chemotactic behaviour analysed. The $\operatorname{Tn} 5$ insertion site of a mutant which did not swarm to mannitol, JPA131, was cloned as a kanamycin-resistant $9.5 \mathrm{kbp} \mathrm{EcoRI} \mathrm{fragment} \mathrm{into} \mathrm{pUC18,}$ generating plasmid pAUL57. A DNA section flanking the Tn5 was excised as $H p a I-E c o R I$ fragment from pAUL57, filled-in with Klenow and blunt-end cloned into the SmaI site of pUC18, generating pAUL65. pAUL65 was sequenced with primers Tn5SEQ and pUCFOR.

Insertional inactivation of the glucose-6-phosphate dehydrogenase gene (zwf). Plasmid pBM1 was used to insertionally inactivate the chromosomal $z w f$ gene. It was constructed from a $0.4 \mathrm{kbp} E c o \mathrm{RI}-B g / \mathrm{II}$ fragment of pAUL65 ligated into the EcoRI/BamHI site of the suicide vector pJP5603 (Penfold \& 
Pemberton, 1992). pBM1 was conjugated into $R$. sphaeroides WS8N and JPA117 from E. coli S17-1 $\lambda$ pir and transconjugants were selected on kanamycin and nalidixic acid, generating strains JPA142 and JPA141 respectively. The interruption of the $z w f$ gene was confirmed by Southern blotting using the $0.4 \mathrm{kbp} E$ coRI-BglII fragment as a probe.

\section{RESULTS}

\section{Chemotaxis}

R. sphaeroides (strain WS8) grew well, both heterotrophically and photoheterotrophically, on fructose, glucose and mannitol, and more slowly on mannose. A positive chemotactic response occurred to all these carbohydrates in plug plate assays (Table 2). Bacterial cells grown on succinate as the carbon source showed weak responses to some carbohydrates. If the cells were grown on the chemoattractant under test then the chemotactic response to that chemoattractant was strong. Thus the taxis to $20 \mathrm{mM}$ glucose in a $2.5 \%(\mathrm{w} / \mathrm{v}$ ) agar plug was stronger in cells grown on M22 medium with glucose as the sole carbon source. None of these carbohydrates were repellents, and indeed no repellents have been identified for $R$. sphaeroides (Armitage et al., $1990 \mathrm{~b}$ ). Chemotaxis to organic acids, such as succinate, pyruvate, propionate or acetate, was equally strong in cells grown with either organic acids or carbohydrates as sole carbon sources (data not shown).

\section{Transport}

Rates of carbohydrate transport were higher if the bacteria were grown on the carbohydrate under test (Table 2). Thus the chemotactic response to carbohydrates in general correlated with the ability of cells to transport these substrates. Furthermore, sugar analogues, such as methyl $\alpha$-D-glucoside or 2-deoxyglucose were not transported and did not produce a tactic response (Table 2). This confirmed the results of Ingham \& Armitage (1987) and subsequent work (Poole \& Armitage, 1989; Poole et al., 1993) which showed that the minimum requirement for chemotaxis to occur in $R$. sphaeroides was transport.

\section{Incorporation}

The rate at which the substrates were incorporated into intracellular trichloroacetic-acid-insoluble material following transport gave an indication of the rate at which the substrate was metabolized. Fructose was incorporated at a mean rate of $10 \mathrm{nmol}(\mathrm{mg} \text { cell protein })^{-1}$ $\mathrm{min}^{-1}$ by fructose-grown cells; glucose was incorporated at $24 \mathrm{nmol}(\mathrm{mg} \text { cell protein })^{-1} \mathrm{~min}^{-1}$ by glucose-grown cells; mannitol at $20 \mathrm{nmol}(\mathrm{mg} \text { cell protein })^{-1} \mathrm{~min}^{-1}$ by mannitol-grown cells and mannose at $3 \mathrm{nmol}(\mathrm{mg}$ cell protein) $)^{-1} \min ^{-1}$ by mannose-grown cells. Succinategrown cells showed rates of incorporation of approximately $1 \mathrm{nmol}$ (mg cell protein) ${ }^{-1} \mathrm{~min}^{-1}$ for glucose, mannose and mannitol and a slightly higher rate of 4 $\mathrm{nmol}$ (mg cell protein) ${ }^{-1} \mathrm{~min}^{-1}$ for fructose. The values, representing the means of three experiments, correlate well with the mean transport rates shown in Table 2. The strength of the chemotactic responses obviously does not correlate directly with the absolute rate of transport and incorporation of individual sugars and this probably reflects the different metabolic pathways into which individual sugars go. This is supported by the data from the $z w f$ mutant (see below).

\section{The PEP-dependent PTS}

Saier et al. (1971) showed that a fructose-specific PTS exists in purple photosynthetic bacteria and a detailed investigation of the PTS in $R$. sphaeroides strain 2.4.1

Table 2. Chemotaxis to and transport of attractants by $R$. sphaeroides pre-grown on succinate or on the attractant under test

Chemotaxis was measured in soft agar plates with agar plugs containing $20 \mathrm{mM}$ attractant. The chemotactic response was observed as a band of accumulation around the hard agar plugs and was graded as follows: ++ , strong; + , weak; 0 , absent. Transport of attractant was measured as described in Methods, using $4 \mu \mathrm{M}$ attractant.

\begin{tabular}{|c|c|c|c|c|}
\hline \multirow[t]{3}{*}{ Attractant } & \multicolumn{2}{|c|}{$\begin{array}{c}\text { Chemotactic response in cells } \\
\text { pre-grown on: }\end{array}$} & \multicolumn{2}{|c|}{$\begin{array}{l}\text { Rate of transport of attractant } \\
\left.\text { [nmol (mg cell protein) }{ }^{-1} \min ^{-1}\right] \\
\text { by cells grown on: }\end{array}$} \\
\hline & \multirow[t]{2}{*}{ Succinate } & \multirow{2}{*}{ Attractant } & & \\
\hline & & & Succinate & Attractant \\
\hline Succinate & ++ & ++ & 25 & 25 \\
\hline Fructose & + & ++ & 5 & 15 \\
\hline Glucose & 0 & ++ & 1 & 28 \\
\hline Mannose & 0 & ++ & 2 & 5 \\
\hline Mannitol & + & ++ & 1 & 23 \\
\hline Methyl $\alpha$-D-glucose & 0 & 0 & 0 & 0 \\
\hline 2-Deoxyglucose & 0 & 0 & 0 & 0 \\
\hline
\end{tabular}


Table 3. Phosphorylation of substrates by soluble and cytoplasmic extracts with either PEP or ATP as the phosphoryl donor

+ or - indicates the presence or absence of a component in the assay mixture.

\begin{tabular}{|c|c|c|c|c|c|}
\hline \multirow[t]{2}{*}{ Substrate } & \multicolumn{4}{|c|}{ Component present in assay mixture } & \multirow{2}{*}{$\begin{array}{l}\text { Rate of phosphorylation } \\
{[\mathrm{nmol}(\mathrm{mg} \text { cell protein }} \\
\left.\text {-1) } \mathrm{min}^{-1}\right]\end{array}$} \\
\hline & PEP & ATP & $\begin{array}{l}\text { Membrane } \\
\text { fraction }\end{array}$ & $\begin{array}{l}\text { Cytoplasmic } \\
\text { fraction }\end{array}$ & \\
\hline \multirow[t]{3}{*}{ Fructose } & + & - & + & + & $15 \cdot 6$ \\
\hline & - & + & + & - & $<1 \cdot 0$ \\
\hline & - & + & - & + & $2 \cdot 0$ \\
\hline \multirow[t]{3}{*}{ Mannitol } & + & - & + & + & 0.0 \\
\hline & - & + & + & - & $<1.0$ \\
\hline & - & + & - & + & $1 \cdot 0$ \\
\hline \multirow[t]{3}{*}{ Glucose } & + & - & + & + & 0.0 \\
\hline & - & + & + & - & $<1.0$ \\
\hline & - & + & - & + & $3 \cdot 0$ \\
\hline
\end{tabular}

Table 4. Enzyme activities in the extracts of $R$. sphaeroides cells grown on different substrates under aerobic dark conditions

Abbreviations: PTS, phosphotransferase system ; MDH, mannitol dehydrogenase; FK, fructokinase; F6PK, fructose-6-phosphate kinase; F1PK, fructose-1-phosphate kinase.

\begin{tabular}{|c|c|c|c|c|c|}
\hline \multirow[t]{2}{*}{ Growth substrate } & \multicolumn{5}{|c|}{ Enzyme activity [nmol (mg cell protein) $\left.{ }^{-1} \mathrm{~min}^{-1}\right]$} \\
\hline & PTS & $\mathbf{M D H}$ & FK & F6PK & F1PK \\
\hline Succinate & $3 \cdot 6$ & 5.9 & $11 \cdot 9$ & $6 \cdot 5$ & $10 \cdot 7$ \\
\hline Fructose & $11 \cdot 6$ & $6 \cdot 0$ & $13 \cdot 1$ & $11 \cdot 6$ & $20 \cdot 6$ \\
\hline Mannitol & $10 \cdot 1$ & $14 \cdot 3$ & $22 \cdot 6$ & $5 \cdot 0$ & $28 \cdot 4$ \\
\hline Glucose & $6 \cdot 3$ & $3 \cdot 1$ & $9 \cdot 3$ & $3 \cdot 6$ & $23 \cdot 8$ \\
\hline
\end{tabular}

was carried out by Robillard (Lolkema \& Robillard, 1985; Lolkema et al., 1985, 1986). The data for $R$. sphaeroides WS8 corresponded well with previous investigations and showed that fructose was the only one of the carbohydrates under investigation which was phosphorylated by PEP. The phosphorylation only occurred in the presence of bacterial membrane and cytoplasmic extracts containing, respectively, EII and EI, essential for PTS function (Table 3). When ATP replaced PEP, the extent of fructose phosphorylation by fructose-grown cells was significantly lower and was primarily in the cytoplasmic fraction (Table 3) containing the ATP-dependent enzymes of sugar catabolism (Lolkema et al., 1985).

Fructose PTS activity was found to be high in both fructose-grown and mannitol-grown cells, but low in glucose-grown and succinate-grown cells (Table 4). The PTS induced by growth on mannitol appeared to be the same as the PTS induced in fructose-grown cells. Both phosphorylated fructose at comparable rates (Table 4) and were fructose-specific (Table 3). Mannitol is converted into fructose intracellularly by mannitol de- hydrogenase and this probably explains the ability of mannitol to induce the fructose PTS as well as its own transport system.

\section{The role of the PTS in chemotaxis}

A chemotactic response occurred to all the carbohydrates under investigation (Table 2). Only fructose, however, was transported through a PTS, the other carbohydrates utilizing different transport mechanisms. This suggests that in $R$. sphaeroides the chemotactic response is independent of the type of transport system.

Substrate competition experiments were carried out to identify whether transport alone could cause chemotactic signalling. Mannitol-grown cells were used as they had a high fructose PTS activity (Table 4) and also transported mannitol at high rates through another, non-PTS, transport system. If a saturating background of $100 \mathrm{mM}$ mannitol was present in the chemotaxis plate, then the chemotaxis to $20 \mathrm{mM}$ fructose was weaker and the incorporation of fructose was lower. The rates are presented as the means \pm SD. Fructose was 
incorporated at a lower rate of $3.75 \pm 0.07 \mathrm{nmol}$ (mg cell protein $)^{-1} \mathrm{~min}^{-1}$ in the presence of a mannitol background, compared to $9.58 \pm 0.74 \mathrm{nmol}(\mathrm{mg}$ cell protein $)^{-1} \min ^{-1}$ with no background $(P=0.000007)$. The mean transport rate of fructose was also reduced, but only slightly, from $11.01 \pm 0.86 \mathrm{nmol}(\mathrm{mg} \text { cell protein })^{-1}$ $\min ^{-1}$ to $9.36 \pm 0.54(P=0.0017)$ in the presence of a mannitol background. $P$ values were calculated using the non-parametric Mann-Whitney test and are presented as two-tailed comparisons. The difference between the incorporation rates was more significant than between the transport rates, suggesting that the weaker response might be due to the incorporation step rather than the transport.

Similarly a background of fructose reduced the mean rate of mannitol transport from $23.08 \pm 1.86 \mathrm{nmol}(\mathrm{mg}$ cell protein $)^{-1} \mathrm{~min}^{-1}$ to $15.11 \pm 0.9 \mathrm{nmol}(\mathrm{mg}$ cell protein) $)^{-1} \mathrm{~min}^{-1}$ and the mean rate of incorporation from $20.51 \pm 1.27 \mathrm{nmol}(\mathrm{mg} \text { cell protein) })^{-1} \mathrm{~min}^{-1}$ to $12.3 \pm$ $0.56 \mathrm{nmol}\left(\mathrm{mg}\right.$ cell protein) ${ }^{-1} \mathrm{~min}^{-1}$ and resulted in a weaker chemotactic response towards mannitol. Saturating backgrounds of either mannitol or fructose did not completely inhibit either the transport or chemotaxis to fructose or mannitol respectively, suggesting that although the sugars share some metabolic pathways, they may also use alternative pathways.

\section{Enzyme activities}

A range of enzymes involved in sugar catabolism were derepressed in $R$. sphaeroides after growth on different carbohydrates (Table 4). Growth on fructose induced the fructose PTS, fructose-6-phosphate kinase and fructose-1-phosphate kinase. Mannitol induced mannitol dehydrogenase and fructokinase suggesting that, as mannitol was not phosphorylated by the induced fructose PTS, it was transported via a non-PTS pathway and converted into fructose intracellularly. The higher levels of enzyme activity measured in mannitol-grown cells may reflect the higher levels of intracellular fructose resulting from the faster rate of mannitol transport.

\section{Identification of a mannitol chemotaxis minus mutant}

Previous attempts in this laboratory to identify a chemotaxis mutant of wild-type $R$. sphaeroides WS8N by $\operatorname{Tn} 5$ transposon mutagenesis were unsuccessful. We now attribute this effect to multiple chemosensory pathways which may compensate for mutations. To overcome this problem, JPA117, which lacks one set of chemotaxis genes but still shows sugar chemotaxis, was mutagenized with $\mathrm{Tn} 5:: \mathrm{Km}$ and grown to single colonies on agar plates containing $7 \mathrm{mM}$ succinate, $0.1 \%$ Casamino acids, kanamycin $\left(25 \mu \mathrm{g} \mathrm{ml}^{-1}\right)$ and nalidixic acid $\left(20 \mu \mathrm{g} \mathrm{ml}^{-1}\right)$. More than 1000 single colonies were picked and grown independently to stationary phase. Each colony was tested independently for swarming using $0 \cdot 22 \%$ agar containing $100 \mu \mathrm{M}$ mannitol. Reduced swarmers were identified and the swarm plate response repeated three or four times until a stable phenotype was obtained. Only one mutant was obtained with a stable phenotype and this strain was labelled JPA131.

The sequence of the mutated gene showed $99 \%$ identity at the DNA level with the $z w f$ gene from $R$. sphaeroides 2.4.1 ( $T$. Conway, personal communication), confirming that the interrupted gene in JPA131 encodes the enzyme glucose-6-phosphate dehydrogenase.

To confirm the phenotype of JPA131 and to further characterize a mutation in the $z w f$ gene, interruption mutations of the $z w f$ gene in WS8N and JPA117 were created using the suicide vector $\mathrm{pBM} 1$, which contained an internal fragment of $z w f$. The chromosomal copy of $z w f$ gene was insertionally inactivated by a single homologous recombination event. A Southern blot, using the $0.4 \mathrm{kbp}$ insert of $\mathrm{pBM} 1$ as a probe, confirmed that the chromosomal copy of the zwf in WS8N and JPA117 had been disrupted (data not shown). These strains were labelled JPA142 and JPA141 respectively.

\section{Phenotypic analysis of the zwf interruption mutant}

Preliminary analysis of all the $z w f$ interruption mutants (JPA131, JPA141 and JPA142) showed their chemotactic behaviour and metabolism to be very similar to, but distinct from, that of wild-type $R$. sphaeroides WS8N. Since JPA141 is deleted for the characterized chemotaxis operon of $R$. sphaeroides whilst JPA142 retains the operon, this suggests that the operon does not have a major role in the normal chemotactic response. A more subtle role in sugar chemotaxis was suggested in a previous study (Hamblin et al., 1997). A detailed investigation of the phenotype of JPA142 was made.

The rate of mannitol transport was found to be the same in JPA142 and WS8N, $10 \cdot 2 \pm 2 \cdot 4 \mathrm{nmol}(\mathrm{mg}$ cell protein) $)^{-1} \mathrm{~min}^{-1}$ and $11.6 \pm 0.4 \mathrm{nmol}(\mathrm{mg} \text { cell protein })^{-1}$ $\mathrm{min}^{-1}$ respectively. To ensure that the mannitol uptake and metabolic enzymes were fully induced, WS8N and JPA142 were grown on an M22-based medium supplemented with succinate, mannitol and Casamino acids.

The activity of glucose-6-phosphate dehydrogenase activity in WS8N and JPA142 grown on an M22 medium supplemented with succinate, mannitol and Casamino acids was $52 \pm 1.9 \mathrm{nmol}(\mathrm{mg} \text { cell protein) })^{-1} \mathrm{~min}^{-1}$ and $<1 \mathrm{nmol}$ (mg cell protein) ${ }^{-1} \mathrm{~min}^{-1}$ respectively, confirming that the $z w f$ gene had been insertionally inactivated.

Under aerobic or anaerobic conditions, JPA142 showed a $50-90 \%$ reduction on swarm plates compared with WS8N when the carbon source was $100 \mu \mathrm{M}$ fructose, mannitol or glucose, although the most significant reduction in swarming was seen with JPA142 on $100 \mu \mathrm{M}$ mannitol under aerobic conditions (Table 5). Swarming to weak organic acids such as acetate and propionate was unaffected.

A comparison of the plug plate responses of JPA142 and wild-type cells grown on a combined succinate/ 
Table 5. Comparison of swarm plate responses of WS8N and JPA142

Cells were inoculated onto $0.22 \%$ agar plates made from M22 medium, nalidixic acid $\left(20 \mu \mathrm{g} \mathrm{ml}^{-1}\right)$ and $100 \mu \mathrm{M}$

chemoattractant. Plates were incubated either aerobically or anaerobically for 1-3 d. + , Weak response; +++++ , strong response, measured as both diameter and strength of swarm.

\begin{tabular}{|lcc|}
\hline Chemoattractant & \multicolumn{2}{c|}{ Swarm plate response of: } \\
\cline { 2 - 3 } & WS8N & JPA142 \\
\hline Aerobic & & \\
Propionate & +++++ & +++++ \\
Fructose & +++++ & ++ \\
Glucose & +++++ & +++ \\
Mannitol & +++++ & + \\
Anaerobic & & \\
Propionate & +++++ & +++++ \\
Fructose & +++++ & +++ \\
Glucose & +++++ & +++ \\
Mannitol & +++++ & $+/-$ \\
\hline
\end{tabular}

carbohydrate medium was also made. Under anaerobic conditions, JPA142 showed a significantly reduced chemotactic response to sugars such as fructose, mannitol and glucose, although the responses to propionate and oxygen were the same as the wild-type.

The behaviour of free-swimming cells was analysed using the Hobson Bactracker. WS8N had a mean swimming speed of $16.0 \pm 0.7 \mu \mathrm{m} \mathrm{s}^{-1}$ and a stopping frequency of $1.7 \pm 0 \cdot 1$ stops s $\mathrm{s}^{-1}$ while JPA142 had a mean swimming speed of $16.4 \pm 0.2 \mu \mathrm{m} \mathrm{s}^{-1}$ and a stopping frequency of $1 \cdot 7 \pm 0 \cdot 1$ stops $\mathrm{s}^{-1}$, confirming that there was no difference in free-swimming behaviour in unstimulated conditions. In the tethered cell analysis, anaerobic WS8N cells responded to a stepped increase in the mannitol concentration ( 0 to $2 \mathrm{mM}$ ) with a small increase in the probability of stopping, which adapted back to pre-stimulus behaviour within $3 \mathrm{~min}$. JPA142 showed a very reduced and more transient response. The response of JPA142 to the addition and removal of $1 \mathrm{mM}$ acetate was identical to that of the wild-type.

The growth rate of JPA142 was compared with that of WS8N on a variety of carbon sources. When grown on succinate medium (M22 medium containing $7 \mathrm{mM}$ succinate and $0 \cdot 1 \%$ Casamino acids), there was no difference in the growth rate between JPA142 and WS8N. In contrast, the growth of JPA142 on M22 medium containing either $7 \mathrm{mM}$ glucose, fructose and mannitol was significantly inhibited unless Casamino acids were added to the growth medium. In the presence of $0.1 \%$ Casamino acids, however, JPA142 was able to grow aerobically extremely slowly on fructose (a doubling time of almost $20 \mathrm{~h}$ ) but not at all on mannitol or glucose. Anaerobically JPA142 could grow, if Casamino acids were present, on fructose, slowly on glucose and very slowly on mannitol.

\section{DISCUSSION}

Previous work with $R$. sphaeroides has suggested that transport and partial metabolism are required to produce a chemotactic response. Although a chemotaxis operon and $m c p$ genes have now been identified in $R$. sphaeroides and there is evidence for multiple pathways, little is known about their function in chemosensing in R. sphaeroides (Ward et al., 1995a, b). In E. coli, sugars are sensed using the MCP-dependent or PTS system which integrate at the histidine protein kinase, CheA (Hazelbauer et al., 1990; Lengeler \& Vogler, 1989; Rowsell et al., 1995; Lux et al., 1995). Here we investigated the chemotactic responses of $R$. sphaeroides to various carbohydrates and the role of metabolism in this process.

$R$. sphaeroides strain WS8 grew well on the four carbohydrates tested, in contrast to strain 2.4.1, which grew poorly (Szymona \& Doudoroff, 1960). Fructose, but not the other carbohydrates, was transported through a fructose-specific PTS. R. sphaeroides showed strong chemotaxis towards a range of carbohydrates, but only if grown on them, suggesting that there are not constitutive MCP-like sugar receptors. Mannitol did not compete with fructose for transport through the fructose PTS system but did compete in chemotaxis assays. As mannitol is converted to fructose intracellularly, this suggests that chemotactic competition takes place at the level of metabolism rather than transport. This was in contrast to enteric bacteria, where the PTS has a definite function in chemotaxis (Grübl et al., 1990; Postma \& Lengeler, 1985; Taylor \& Lengeler, 1990). There is no evidence for other carbohydrate transport systems being involved in chemotaxis in enteric bacteria.

The induction of a particular carbohydrate chemotactic system corresponded to the induction of the transport system and the catabolic pathways for that substrate. This suggests that the metabolic pathways induced or derepressed by growth on carbohydrates have a crucial function in chemotactic signalling to those substrates. Little is known about the metabolic pathways of $R$. sphaeroides or their change in activity under aerobic and anaerobic conditions, but the Embden-Meyerhof, Entner-Doudoroff and pentose phosphate pathways all operate and it seems probable from the data from the $z w f$ mutant that the sugars feed into different pathways to different extents under different growth conditions. A saturating background of mannitol reduced the rate of fructose incorporation and also the strength of the chemotactic response to fructose, but did not completely inhibit either. Fructose transported by the PTS was concomitantly phosphorylated to fructose 1-phosphate and is then probably converted to fructose 1,6-bisphosphate by fructose-1-phosphate kinase. Mannitol was probably transported by a non-PTS mannitol transport system and converted into fructose intra- 
cellularly by mannitol dehydrogenase, catabolized by a fructokinase to fructose 6-phosphate and converted to fructose 1,6-bisphosphate (Lolkema et al., 1985). All these enzymes were present and active in $R$. sphaeroides WS8 grown on fructose, glucose and mannitol. It is likely that the intracellular competition for this catabolic pathway, shown by the considerably lower rate of fructose incorporation in the presence of a mannitol background, gave rise to the weaker chemotactic response.

JPA142 was originally isolated as a mutant in chemotaxis to mannitol. Sequence analysis of the $\operatorname{Tn} 5$ insertion site showed that the interrupted gene did not encode a sensory protein such as an MCP, but instead was a metabolic enzyme, glucose-6-phosphate dehydrogenase, a key enzyme in the Entner-Doudoroff pathway. Detailed analysis of this mutant showed that, although it was defective in chemotaxis towards mannitol and partially defective in chemotaxis towards glucose and fructose, its mannitol uptake and taxis to organic acids such as succinate, propionate and acetate were identical to the wild-type. The observation that the mutant could still grow under some conditions on glucose and fructose, and showed chemotaxis to these sugars, emphasizes the complexity of $R$. sphaeroides metabolism. The weak response to glucose and fructose and the differences in responses under aerobic and anaerobic conditions probably reflect the use of the EmbdenMeyerhof pathway under these conditions and the partial by-passing of the Entner-Doudoroff pathway block caused by the $z w f$ mutation, whereas mannitol must be exclusively metabolized through the EntnerDoudoroff pathway. This ability to channel sugars through different metabolic pathways is probably reflected in the different strengths of chemotactic responses under different conditions and the competition seen between sugars. The ability of JPA142 to show a tactic response correlates very closely with its ability to metabolize a particular chemoattractant.

The data presented here show that the chemotaxis to the carbohydrates is MCP-independent in R. sphaeroides. All the carbohydrates were chemoattractants despite being transported by different transport systems. Since the reduced tactic responses of JPA142, which carries a mutation in the glucose-6-phosphate dehydrogenase gene $(\Delta z w f)$, can be attributed to a block in the Entner-Doudoroff metabolic pathway, we suggest that chemotactic responses to sugars in $R$. sphaeroides are sensed through metabolism and are independent of the mode of transport. The mechanisms by which metabolic activity might control chemotaxis are unknown, but recent data on $E$. coli show that fumarate levels altered by metabolic activity can directly control flagellar activity and it has been suggested that sensing the metabolic state may be an early form of chemotaxis (Montrone et al., 1996). It is also possible that the chemotactic signal results from changes in the redox state of a component of the electron-transport chain, with NADH providing the link between sugar metabolism and electron transport, particularly as mannitol elicits such a strong response and requires a dehydrogenase as the first metabolic step. Redox sensors such as the PrrA/PrrB two-component system, which is involved in the oxygen control of photosynthesis gene expression, are well characterized in $R$. sphaeroides (Eraso \& Kaplan, 1994, 1995) and recent work in this laboratory has shown that redox sensing is involved in tactic responses to light and oxygen (Grishanin et al., 1997). Current work is focused on the identification of the 'sensor' which may link metabolism and electron transport.

\section{ACKNOWLEDGEMENTS}

We would like to thank Dr Bruce Maguire for technical assistance and the BBSRC for grants to Y. J.S. and P.A.H. We are extremely grateful to Dr T. Conway for sharing sequence data from $R$. sphaeroides 2.4 .1 prior to publication.

\section{REFERENCES}

Armitage, J. P. (1992). Behavioral responses in bacteria. Annu Rev Physiol 54, 683-714.

Armitage, J. P. \& Schmitt, R. (1997). Bacterial chemotaxis: Rhodobacter sphaeroides and Sinorhizobium meliloti-variations on a theme? Microbiology 143, 3671-3682.

Armitage, J. P., Ingham, C. \& Evans, M. C. W. (1985). Role of the proton motive force in phototactic and aerotactic responses of Rhodopseudomonas sphaeroides. J Bacteriol 163, 967-972.

Armitage, J. P., Havelka, W. A. \& Sockett, R. E. (1990a). Methylation-independent taxis in bacteria. In Biology of the Chemotactic Response (Society for General Microbiology Symposium 46), pp. 177-198. Edited by J. P. Armitage \& J. M. Lackie. Cambridge: Cambridge University Press.

Armitage, J. P., Poole, P. S. \& Brown, S. (1990b). Sensory signalling in Rhodobacter sphaeroides. In Molecular Biology of Membrane Bound Complexes in Phototrophic Bacteria, p. 406. Edited by G. Drews. New York: Plenum Press.

Berg, H. C. \& Block, S. M. (1984). A minature flow cell designed for rapid exchange of media under high-powered objectives. $J$ Gen Microbiol 130, 2915-2920.

Birnboim, H. C. \& Doly, J. (1979). A rapid alkaline extraction procedure for screening recombinant plasmid DNA. Nucleic Acids Res 7, 1513-1523.

Blat, Y. \& Eisenbach, M. (1994). Phosphorylation-dependent binding of the chemotaxis signal molecule CheY to its phosphatase, CheZ. Biochemistry 33, 902-906.

Conley, M. P., Wolfe, A. J., Blair, D. F. \& Berg, H. C. (1989). Both $\mathrm{CheA}$ and $\mathrm{CheW}$ are required for reconstitution of chemotactic signaling in Escherichia coli. J Bacteriol 171, 5190-5193.

Daniels, G. A., Drews, G. \& Saier, M. H., Jr (1988). Properties of a $\operatorname{Tn} 5$ insertion mutant defective in the structural gene $(f r u A)$ of the fructose specific phosphotransferase system of Rhodobacter capsulatus and cloning the fru regulon. J Bacteriol 170, 16981703.

Eraso, J. M. \& Kaplan, S. (1994). prrA, a putative response regulator involved in oxygen regulation of photosynthesis gene expression in Rhodobacter sphaeroides. J Bacteriol 176, 32-43.

Eraso, J. M. \& Kaplan, S. (1995). Oxygen-insensitive synthesis of the photosynthetic membranes of Rhodobacter sphaeroides: a mutant histidine kinase. J Bacteriol 177, 2695-2706. 
Fraenkel, D. G. (1968). The phosphenolpyruvate pathway of fructose metabolism in Escherichia coli. J Biol Chem 243, 6453-6463.

Geerse, R. H., Izzo, F. \& Postma, P. W. (1989). The PEP: fructose phosphotransferase system in Salmonella typhimurium: FPr combines enzyme III $^{\text {Fru }}$ and pseudo-HPr activities. Mol Gen Genet 216, 517-525.

Grishanin, R. N., Gauden, D. E. \& Armitage, J. P. (1997). Photoresponses in Rhodobacter sphaeroides: role of photosynthetic electron transport. J Bacteriol 179, 24-30.

Grubl, G., Vogler, A. P. \& Lengeler, J. W. (1990). Involvement of the histidine protein $(\mathrm{HPr})$ of the phosphotransferase system in chemotactic signaling of Escherichia coli K-12. J Bacteriol 172, 5871-5876.

Hamblin, P. A., Bourne, N. A. \& Armitage, J. P. (1997). Characterisation of the chemotaxis protein CheW from Rhodobacter sphaeroides and its effect on the behaviour of Escherichia coli. Mol Microbiol 24, 41-51.

Hazelbauer, G. L., Yaghmai, R., Burrows, G. G., Baumgartner, J. W., Dutton, D. P. \& Morgan, D. G. (1990). Transducers: transmembrane receptor proteins involved in bacterial chemotaxis. In Biology of the Chemotactic Response, pp. 107-134. Edited by J. P. Armitage \& J. M. Lackie. Cambridge: Cambridge University Press.

Hess, J. F., Oosawa, K., Kaplan, N. \& Simon, M. I. (1988). Phosphorylation of three proteins in the signalling pathway of bacterial chemotaxis. Cell 53, 79-87.

Holzapfel, W., Finkele, U., Kaiser, W., Oesterhelt, D., Scheer, H., Stilz, H. U. \& Zinth, W. (1990). Initial electron-transfer in the reaction center from Rhodobacter sphaeroides. Proc Natl Acad Sci USA 87, 5168-5172.

Ingham, C. J. \& Armitage, J. P. (1987). Involvement of transport in Rhodobacter sphaeroides. J Bacteriol 169, 5801-5807.

Jacobs, M. H. J., van der Heide, T., Tolner, B., Driessen, A. J. M. \& Konings, W. N. (1995). Expression of the gltp gene of Escherichia coli in a glutamate transport-deficient mutant of Rhodobacter sphaeroides restores chemotaxis to glutamate. Mol Microbiol 18, 641-647.

Lengeler, J. W. \& Vogler, A. P. (1989). Molecular mechanisms of bacterial chemotaxis towards PTS-carbohydrates. FEMS Microbiol Rev 63, 81-92.

Lolkema, J. S. \& Robillard, G. T. (1985). Phosphoenolpyruvatedependent fructose system in Rhodopseudomonas sphaeroides. Eur J Biochem 147, 69-75.

Lolkema, J. S., Ten Hoeve-Duukens, R. H. \& Robillard, G. (1985). The phosphoenolpyruvate-dependent fructose specific phosphotransferase system in Rhodopseudomonas sphaeroides. Mechanism of transfer of the phosphoryl group from phosphoenolpyruvate to fructose. Eur J Biochem 149, 625-631.

Lolkema, J. S., Ten Hoeve-Duurkens, R.H. \& Robillard, G. T. (1986). The phosphoenolpyruvate-dependent fructose-specific phosphotransferase system in Rhodopseudomonas sphaeroides. Eur J Biochem 161, 211-215.

Lux, R., Jahreis, K., Bettenbrock, K., Parkinson, J. S. \& Lengeler, J. W. (1995). Coupling the phosphotransferase system and the methyl-accepting chemotaxis protein-dependent chemotaxis signaling pathways of Escherichia coli. Proc Natl Acad Sci USA 92, 11583-11587.

Messing, J. (1983). New M13 vectors for cloning. Methods Enzymol 101, 20.

Miller, V. L. \& Mekalanos, J. J. (1988). A novel suicide vector and its use in the construction of insertion mutants: osmoregulation of outer membrane proteins and virulence in Vibrio cholerae requires toxR. J Bacteriol 170, 2575-2583.

Montrone, M., Oesterhelt, D. \& Marwan, W. (1996). Phosphorylation-independent bacterial chemoresponses correlate with changes in the cytoplasmic levels of fumarate. J Bacteriol 178, 6882-6887.

Niwano, M. \& Taylor, B. L. (1982). Novel sensory adaptation mechanism in bacterial chemotaxis to oxygen and phosphotransferase substrates. Proc Natl Acad Sci USA 79, 11-15.

Penfold, R. J. \& Pemberton, J. M. (1992). An improved suicide vector for construction of chromosomal insertion mutations in bacteria. Gene 118, 145-146.

Poole, P. S. \& Armitage, J. P. (1989). Role of metabolism in the chemotactic response of Rhodobacter sphaeroides to ammonia. J Bacteriol 171, 2900-2902.

Poole, P. S., Sinclair, D. R. \& Armitage, J. P. (1988). Real time computer tracking of free-swimming and tethered rotating cells. Anal Biochem 175, 52-58.

Poole, P. S., Smith, M. J. \& Armitage, J. P. (1993). Chemotactic signalling in Rhodobacter sphaeroides requires metabolism of attractants. J Bacteriol 175, 291-294.

Postma, P. W. \& Lengeler, J. W. (1985). Phosphoenolpyruvate:carbohydrate phosphotransferase system of bacteria. Microbiol Rev 49, 232-269.

Rowsell, E. H., Smith, J. M., Wolfe, A. \& Taylor, B. L. (1995). CheA, $\mathrm{CheW}$, and $\mathrm{CheY}$ are required for chemotaxis to oxygen and sugars of the phosphotransferase system in Escherichia coli. $J$ Bacteriol 177, 6011-6014.

Saier, M. H., Jr (1989). Protein phosphorylation and allosteric control of inducer exclusion and catabolite repression by the bacterial phosphoenolpyruvate:sugar phosphotransferase system. Microbiol Rev 53, 109-120.

Saier, M. H., Jr (1993). Regulatory interactions involving the proteins of the phosphotransferase system in enteric bacteria. $J$ Cell Biochem 51, 62-68.

Saier, M. H., Jr, Fuecht, B. U. \& Roseman, S. (1971). Phosphoenolpyruvate-dependent fructose phosphorylation in photosynthetic bacteria. J Biol Chem 246, 7819-7821.

Saier, M. H., Jr, Wu, L.-F., Baker, M. E., Sweet, G., Reizer, A. \& Reizer, J. (1990). Evolution of permease diversity and energycoupling mechanisms with special reference to the bacterial phosphotransferase system. Biochim Biophys Acta Bio-Energetics 1018, 248-251.

Sambrook, J., Fritsch, E. F. \& Maniatis, T. (1989). Molecular Cloning: a Laboratory Manual, 2nd edn. Cold Spring Harbor, NY: Cold Spring Harbor Laboratory.

Simon, R., Priefer, U. \& Puhler, A. (1983a). Vector Plasmids for in vivo and in vitro manipulations of Gram-negative bacteria. In Molecular Genetics of the Bacteria-Plant Interaction, p. 99. Edited by A. Puhler. Berlin: Springer.

Simon, R., Priefer, U. \& Puhler, A. (1983b). A broad host range mobilization system for in vivo genetic engineering: transposon mutagenesis in Gram-negative bacteria. BioTechnology 1, 784 794.

Sockett, R. E., Foster, J. C. A. \& Armitage, J. P. (1990). Molecular biology of the Rhodobacter sphaeroides flagellum. FEMS Symp 53, 473-479.

Stock, J., Borczuk, A., Chiou, F. \& Burchenal, J. (1985). Compensatory mutations in receptor function: a re-evaluation of the role of methylation in bacterial chemotaxis. Proc Natl Acad Sci USA 82, 8364-8368. 
Szymona, M. \& Doudoroff, M. (1960). Carbohydrate metabolism in Rhodopseudomonas sphaeroides. J Gen Microbiol 22, 167183.

Tabor, S. \& Richardson, C. C. (1987). DNA sequence analysis with a modified bacteriophage T7 DNA polymerase. Proc Natl Acad Sci USA 84, 4767-4771.

Taylor, B. L. \& Lengeler, J. W. (1990). Transductive coupling by methylated transducing proteins and permeases of the phosphotransferase system in bacterial chemotaxis. In Membrane Transport and Information Storage, pp. 69-90. Edited by R. C. Aloia, C. C. Curtain \& L. M. Gordon. New York: Alan R. Liss.

Ward, M. J., Bell, A. W., Hamblin, P. A., Packer, H. L. \& Armitage, J. P. (1995a). Identification of a chemotaxis operon with two cheY genes in Rhodobacter sphaeroides. Mol Microbiol 17, 357-366.

Ward, M. J., Harrison, D. M., Ebner, M. J. \& Armitage, J. P. (1995b). Identification of a methyl-accepting chemotaxis protein in Rhodobacter sphaeroides. Mol Microbiol 18, 115-121.

Wu, L.F., Tomich, J. M. \& Saier, M. H., Jr (1990). Structure and evolution of a multidomain multiphosphoryl transfer protein. Nucleotide sequence of the $f r u B(H I)$ gene in Rhodobacter capsulatus and comparisons with homologous genes from other organisms. J Mol Biol 213, 687-703.

Wu, L.-F., Reizer, A., Reizer, J., Cai, B., Tomich, J. M. \& Saier, M. H., Jr (1991). Nucleotide sequence of the Rhodobacter capsulatus fruK gene, which encodes fructose-1-phosphate kinase: evidence for a kinase superfamily including both phosphofructokinases of Escherichia coli. J Bacteriol 173, 3117-3127.

Yanisch-Perron, C., Vieira, J. \& Messing, J. (1985). Improved M13 phage cloning vectors and host strains: nucleotide sequences of the M13mp18 and pUC19 vectors. Gene 33, 103-119.

Yonekawa, H., Hayashi, H. \& Parkinson, J. S. (1983). Requirement of the cheB function for sensory adaptation in Escherichia coli. $J$ Bacteriol 156, 1228-1235.

Received 19 June 1997; revised 9 September 1997; accepted 19 September 1997. 